\title{
IMPACT OF CORPORATE GOVERNANCE FAILURE ON PUBLIC TRUST: AN EVIDENCE FROM INDIA
}

\author{
Dr. Gagan Kukreja \\ Associate Professor \\ Department of Accounting, Finance and Banking \\ College of Business and Finance \\ Ahlia University, Bahrain \\ E-mail: gkukreja@ahlia.edu.bh
}

\begin{abstract}
This research study explores the maligned role of Chanda Kochhar, the top-notch executive of ICICI Bank, a leading multinational and financial service provider. An alleged corruption case was filed against her under the Prevention of Money Laundering Act. The case was filed against her after a whistleblower alleged that the bank had given INR 32.50 billion to Videocon group in 2012, the majority of which was declared as Non-Performing Assets later by the bank. This research study focuses on misused the position for personal gains. It touches upon the board of directors of an organisation's fiduciary role and tries to outline whistleblowers' importance in corporate governance. The study unravels the conflicts of interest, alleged corruption, lack of disclosures of related party transactions required by corporate governance principles, and quid-pro-quo. The study will deliberate the impact of such alleged corruption on the various stakeholders, especially shareholders. The study is exploratory and qualitative and based on publicly available information. Other corroborative evidence verifies the reliability of the information. This study will offer suggestions to improve the corporate governance principles to the regulators.
\end{abstract}

Keywords: Compliance Challenges, Corporate Governance, Conflict of Interest, Nepotism, Fiduciary Duties, Non-Performing Assets.

JEL Classification Codes: D73, D74, G21, G34.

\section{INTRODUCTION}

Shalini Garg was appointed as a content writer at Finscoop, a start-up in Mumbai that plans to curate content related to India's financial and economic matters. The founder of the start-up, Mitesh Misra, a pass-out of Delhi School of Economics, was passionate about spreading financial awareness among people and wanted the brand to be a platform that would be the beginners' guide to the world of finance, and bring exclusive videos, news updates, courses, blogs, and many other products, aimed at bringing the latest news in most innovative ways to the citizens of the country. Misra had told Garg specifically that they were hoping to increase the awareness of young readers by offering breaking news that would attract eyeballs and open their eyes to some realities of the financial world.

While she was brainstorming with her team about the platform's stories, the team stumbled upon the headlines that were doing rounds. It was about Chanda Kochar, the CEO, and MD of ICICI Bank. For anyone who idolised successful women in the corporate sector, Chanda Kochar's career was 
ubiquitous. However, recently, a whistleblower exposed the news of big NPAs reported by ICICI bank caused by a loan to Deepak Kochar, Chanda's husband (Choudhary, 2019). Garg and her team got all excited to explore and present to Misra their version of the story and the ramifications that it could have for the Indian Banking system. From what they read from various sources, "Kochhar, her husband, and Dhoot were booked by the CBI for charges of cheating and corruption in sanctioning loans to the Videocon Group, which caused a loss of INR 17.30 bn to the bank" (Gadgil, 2018). Garg was sure that her readers would like to know how the case had unfolded.

\section{Background of the Company}

ICICI Bank was incorporated in 1994. It is one of India's largest retail private banks, and its shares are listed on the Indian stock exchange. The total consolidated assets of the bank were \$200 billion as of September 30, 2020. The shares of the bank are listed on New York Stock Exchange. As per the bank's website ICICI Bank currently has a network of 5,288 branches and 15,158 ATMs across India. The bank has operations overseas as well.

\section{People Involved in the Alleged Fraud}

Chanda Kochhar started her career as a management trainee in 1984. She rapidly climbed the ladder of success, and finally, in 2009, she was appointed as the CEO and MD of the Bank. Before her elevation, she played a significant and instrumental role in setting up the bank, oversaw retail banking\& was also the Chief Financial Officer. She was the first female to hold the topmost position of an Indian bank and was admired for her fight of one of the most challenging succession battles in corporate India's history. For more than a decade, she ranked among the country's most influential women and was the most preferred face for India Inc's poster woman. In a society where very few women manage to reach the corporate ladder's top rungs, Chanda Kochhar had broken the glass ceiling. She led the ICICI Bank for more than one decade, and under her leadership, the bank won the "Best Retail Bank in India" award four-time consecutively from 2001 to 2005. Chanda played an essential and significant role in developing and shaping Indian's retail banking. Chanda was always involved in social causes and was given much recognition, and has featured as 'Most Powerful Women'. She was also named in 100 Most Influential People in the world by TIME magazine in 2015 (Gadgil, 2018).

Deepak Kochhar, the husband of Chanda, was a financial services entrepreneur. He graduated with master's of Finance from the JBIMS, Mumbai, India, and an alumnus of Harvard Business School, US. He was the co-founder and CEO of NRPL, which was incorporated in December 2008. NRPL was established as a partnership between Deepak, Venugopal Dhoot of Videocon, and Advani's (Deepak Kochhar's in-laws) (Gadgil, 2018).

Venugopal Dhoot was the founder, chairman, and managing director of Videocon (James, 2021). Arvind Gupta, an investor, and consultant, was the whistleblower who wrote a letter to the Prime Minister's Office (PMO), Finance Minister's Office, and other senior officials in 2016. In his letter, he alleged the Chanda, Deepak, Venugopal, and others for charges of corruption, conflict of interest, quid-pro-quo, nepotism, etc. Further, he claimed that the bank's money was misused for personal gains (Unnikrishnan, 2018).

\section{LITERATURE REVIEW AND HYPOTHESIS DEVELOPMENT}

Venugopal Dhoot of the Videocon group applied for a loan of INR 32.50 billion from ICICI Bank in 2011. The proposal was thoroughly scrutinised by the Bank's Credit Committee comprising eight members; Chanda Kochhar was one. After analysing the loan's viability through business models and computations, this proposal was then sent to the Board of the Bank. Twelve more individuals, including 
Chanda Kochhar, examined the proposal for final validation. The loan was sanctioned in January 2012 as a part of a loan consortium of more than twenty banks and financial institutions for a debt consolidation program to Videocon and twelve of its subsidiaries, in an aggregated amount of INR 400 bn in total. The loan share of ICICI Bank was less than $10 \%$ of the total loan (Choudhary, 2019). This outstanding loan is INR 28.1 bn, four years passed, and the loan became an NPA for ICICI Bank in 2017 (Singh, 2018).

In 2016, Chanda Kochharcame under the lens of revenue and law enforcement agencies of India. The attention was drawn because of Arvind Gupta's complaint, a whistleblower of the case. In his letter to the Prime Minister and other regulators, he accused her of conflict of interest, nepotism, misuse of her position, and corruption. The whistleblower raised red flags demanded an enquiry into the dealings between ICICI Bank, Chanda Kochhar's husband Deepak Kochhar, and Videocon Group promoter. When he realised that the concerned authorities were not paying any heed to the matter, he published the complaint on social media accounts in October 2016 (Unnikrishnan, 2018). In another letter dated May 11, 2018, to the PMO and several regulating agencies further alleged the Chanda Kochhar's on the issue (Asian News International, 2018).

Initially, the matter did not come into the public eyes. The allegation came into the limelight in April 2018 with an investigation carried out by The Indian Express. Arvind Gupta's blog post attracted media attention after almost two years of publication (Naraynan, 2018). It brought out the allegations on Deepak Kochhar, making enormous advantages from his dealing with Venugopal Dhoot. Venugopal Dhoot arranged a massive loan facility for the Videocon group from the ICICI Bank. At that time, ICICI was headed by Chanda Kochhar. But again, it was unsuccessful in proving any mutual benefits (kickback) being extended. On being contacted by the compliance officer, Chanda Kocchar briefed the board in a board meeting about the whole issue. She made a few disclosures in which she stated that NRPL was founded by her husband, Deepak Kochhar, in 2009. In 2010, Venugopal Dhoot, who also owned Supreme Energy, invested a sum of INR $640 \mathrm{mn}$ into the company in exchange for a certain percentage of shares. It was legal as he was nothing but an investor. She further disclosed that in 2013 Venugopal Dhoot had transferred his shares in NRPL to a trust named Pinnacle Energy which Deepak Kochhar controlled. He paid a little less than a million rupees for the transaction. Within three years after giving out a loan to NRPL, Supreme Energy got absorbed by Pinnacle (Choudhary, 2019).

This transaction was legal, just as it gave Deepak Kochhar the power to make all crucial decisions. Finally, she informed the board that the matter was not brought in front of the board as it took place almost two years back, and Deepak Kochhar had gained no monetary benefit due to the loan's sanctioning. The bank's internal processes for credit approval were reviewed and were found foolproof. The Board of the Bank stated that the credit proposal was vetted by a panel of eight experts, including two outsiders and eleven other board directors, who agreed without doubting the proposal. They concluded by saying that the NPA happened due to economic and business factors in Videocon. The board reiterated that though Chanda Kochhar might be ethically wrong in not informing the board about her husband's and Dhoot's association it still had full confidence in Chanda Kochhar and declared that any claims of corruption were baseless.

However, on March 31, 2018, to probe against allegations imposed on Deepak Kochhar, Chanda Kochhar, and others, the Central Bureau of Investigation (CBI) initiated an enquiry. Suspicions arose further when the CBI summoned the brother of Deepak Kochhar, Rajiv Kochhar. CBI alleged that Avista Advisory, the company owned by Rajiv Kochhar, granted loans from the bank. Avistareceived the mandate from their clients to restructure foreign currency-denominated debt deals worth over US\$1.7 bn (Choudhary, 2019). In the same year, in May, The Securities and Exchange Board of India (SEBI) sent a show-cause notice to Chanda Kochhar. Notice asked for an explanation 
of the alleged non-compliance with corporate governance disclosure norms concerning Deepak Kochhar, Venugopal Dhoot, Videocon Group, and her husband's NRPL. The Serious Fraud Investigation Office (SFIO) also got involved. After seeking permission from the Ministry of Corporate Affairs (MCA), it started an investigation to launch a probe into the INR 32.50 bn loan given by the bank to Videocon's group (Singh, 2019).

However, another whistleblower's allegations raised doubts in investors' minds, corporate governance gurus, and the media. It created pressure and forced the Board of the Bank to order a detailed and third-party independent inquiry to look at Chanda Kochhar's violation of the bank's bylaws regarding conflict of interest and related party transactions (Saha, 2018).

In June 2018, ICICI Bank appointed B. N. Srikrishna, former judge of the apex court, to investigate the allegations of corporate misconduct imposed against Chanda Kochhar (Nair, 2018).

Until the probe was completed, Chanda went on indefinite leave. The bank said it is her planned leave (Gadgil, 2018). Sandeep Bakhshi appointed was the Interim CEO during this period (Laskar, 2018). Later on, in October 2018, Chanda Kochhar resigned, even before Judge Krishna's report was submitted. Further, Chanda also left the Board position from the subsidiaries of the bank. Her tenure would have, in normal circumstances, ended in March 2019 (Gadgil, 2018). It is worth noting that Krishna's report did not investigateVideocon's investment in the business of Chanda's husband in consideration for loans.

In January 2019, Chanda, Deepak, and Venugopal were booked by the CBI. The CBI charged them for cheating and corruption. In its charge sheet, the CBI claimed that sanctioning loans to Venugopal's companies caused a loss of INR 17.30 bn to the Bank, and Chanda misused her position and got a favour to her husband in favouring the loan to Videocon Group (Dsouza, 2019). The bureau claimed that soon after her alleviation to the CEO's post, the bank approved six high amount loans to the Videocon group between June 2009 and October 2011. The CBI report claimed that the day the amount was reportedly transferred into the Videocon group of companies; the "very next day"Videocom group company had transferred INR $640 \mathrm{mn}$ to NRPL.

After a few days, the Srikrishna committee submitted the report, and it found Chanda violated many bank by-laws and provisions of corporate governance. Based on the report, the bank decided to revoke all retirement benefits and recouped the bonuses amount a whopping INR $98.2 \mathrm{mn}$ paid to Chanda since 2009. The bank treated her resignation as termination (Hetavkar, 2019). Chanda stated that she was deeply pained and shocked by the bank's decision. Chanda Kochhar was given a termination letter by the Bank (Unnikrishnan, 2019). Later, Chanda filed a petition in the court against her termination decision and termed it "illegal, untenable and unsustainable in law". But the petition was dismissed by the court.

The following hypotheses are derived from the literature as follows:

- The opportunity of wrongdoing leads to corruption and unethical practices.

- The capacity of wrongdoing leads to corruption and unethical practices.

\section{PROBLEM STATEMENT}

The research is focusing on the alleged corruption done by Chanda as she has the opportunity and capacity. The study is focusing on the modus operandi adopted by an alleged corrupt top banker. The study touches upon the failed fiduciary role of the board. Further, it is highlighting the role of whistleblowers in mitigating the alleged corruption. 
CONCEPTUAL FRAMEWORK

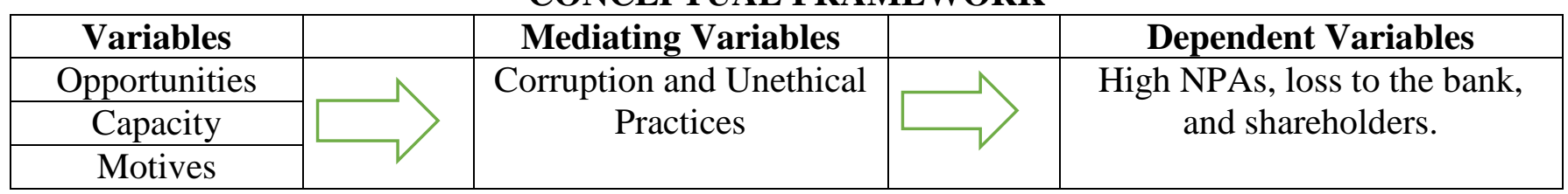

Figure 1. Conceptual Framework

Source: Created by the author

\section{OBJECTIVES}

The study's objective is to explore the modus operandi used by an alleged banker in sanctioning the role. The study focuses on business practices that are legally acceptable but not ethical. It further studies how senior executives' opportunities, capacity, and motives lead to corruption and unethical practices, resulting in the organisation and shareholders' loss. Such an instance also creates a question mark on the transparency in significant business dealings, which has a detrimental impact on the investment community and public.

\section{RESEARCH METHODOLOGY}

This study is exploratory and qualitative. The research information was collected from various credible sources such as investigation reports of investigating agencies, whistleblower reports, reputed newspapers, business magazines, etc. The information verified by corroborating evidence and comparing the information from other sources.

\section{DISCUSSIONS}

The Income Tax department, the Serious Fraud Investigation Office (SFIO), the CBI, and the Directorate of Enforcement (ED) also sought details of the loans disbursed during Chanda's tenure as $\mathrm{MD}$ and CEO. It demanded the bank's reply to the apparent non-compliance with corporate governance disclosure norms regarding the related parties. These agencies also accused Chanda of cheating, dishonesty, and "abusing her official position" by approving the loans to Venugopal's companies. Chanda denied the allegations and said that she and her husband Deepak did not share any business details and were unaware of his relationship with Venugopal. She admitted to the board that she had come to know about her husband's business dealings only later. She also stated that the loan given to Videocon was based purely on merit.

The ED lodged a criminal case of money laundering, based on CBI's FIR against Kochhar's, Venugopal, and investigates senior ICICI bank executives' roles in the bank committee approved the loans (Sharan, 2020). Further, they looked at the loans irregularities approved to Essar Steel, owned by Ravi Ruia, during 2010-11. ED's investigation found that Nishant Kanodia, Ravi Ruia's son-in-law, had invested INR 3 bn in the same period in NPRL through First-hand Holding and Mauritius-based Matrix Pvt. Ltd. (Gadgil, 2018).

The ED arrested Deepak Kochhar on September 8, 2020 (Gupta, 2020). They filed the first charge-sheet against Chanda, Deepak, and Venugopal and alleged them for cheating and money laundering. The investigating agency has also named VIEL, VIL, NRPL, and Supreme Energy Pvt. Ltd in the charge sheet. The announcement came just before the 60-day custody of Deepak, under the Prevention of Money Laundering Act (PMLA), expired on November 8, 2020. He was refused bail on December 1, 2020 (Sharma, 2020).

A charge sheet filed by the ED mentioned that Deepak and Venugopal had appointed fake directors by using the names of house caretakers, relatives, and subordinates. The ED recorded some of 
these fake directors' statements. Some of them admitted they never heard these companies' names and were directors in these companies (Sharan, 2020).

The ED attached the residence, and three other properties belong to Kochhar. The ED estimated the market value of these properties worth INR $6000 \mathrm{mn}$. However, the book value was INR $780 \mathrm{mn}$. The ED has identified one of the flats at CCI Chambers, Mumbai, as an "illegal gain" from Videcon. The PMLA Tribunal ordered the status quo on the properties attached by the ED (Choudhary, 2020). Venugopal defended to the ED that Deepak had threatened him to make his loans declared as NPA prematurely so his and his's family name will be ruined. He transferred the flat to him under fear and pressure over INR $35 \mathrm{mn}$ (Singh, 2020).

Table 1. Timeline of Major Events

\begin{tabular}{|c|c|}
\hline Date & Major Events \\
\hline January 5, 1994 & ICICI Bank Ltd was formed in1994. \\
\hline $\begin{array}{l}\text { December } 24, \\
2008\end{array}$ & $\begin{array}{l}\text { Deepak Kochhar, Venugopal Dhoot, and Saurabh Dhoot are appointed } \\
\text { directors in NPRL (Singh, 2018, March 29). }\end{array}$ \\
\hline January 15, 2009 & $\begin{array}{l}\text { After allotting almost } 20 \text { lakh securities to Deepak Kochhar, Dhoot resigned } \\
\text { from his post (Singh, 2018, March 29). }\end{array}$ \\
\hline May 1, 2009 & Chanda took charge of the CEO and MD. \\
\hline June 5, 2009 & $\begin{array}{l}\text { All securities transferred to Deepak Kochhar owned Supreme Energy (Jai, } \\
2018 \text {, April 5). }\end{array}$ \\
\hline August 26, 2009 & $\begin{array}{l}\text { The first loan of INR } 3 \text { bn sanctioned to Videocon by ICICI Bank } \\
\text { (Dhasmana, 2019, January 5) }\end{array}$ \\
\hline $\begin{array}{l}\text { September } \\
2009\end{array}$ & Loan credited in the account of Videocon (Choudhary, 2019, March 13) \\
\hline $\begin{array}{l}\text { September } \\
2009\end{array}$ & INR 640 mn transferred by Dhoot to NPRL(Jai, 2018, April 5). \\
\hline June 20,2012 & $\begin{array}{l}\text { Loans worth INR } 32.50 \text { bn were sanctioned to Videocon, and Chanda } \\
\text { Kochhar had played an instrumental role in sanctioning these loans (Singh, } \\
\text { 2018, March 29). }\end{array}$ \\
\hline June 30,2017 & $\begin{array}{l}\text { Accounts of Videcon and its group companies declared as NPAs } \\
\text { (Unnikrishnan, 2018, April 3). }\end{array}$ \\
\hline October 2016 & $\begin{array}{l}\text { Arvid Gupta, a whistleblower who held shares in Videocon \& ICICI Bank, } \\
\text { raises concerns about dealings between the Bank, Videocon, and Deepak } \\
\text { Kochhar. However, no heed is paid to the matter. (Unnikrishnan, 2018, June } \\
\text { 1). }\end{array}$ \\
\hline March 28, 2018 & $\begin{array}{l}\text { The Board of the Bank states that it had complete confidence in Chanda } \\
\text { Kochhar and denies all allegations of corruption, nepotism, or conflict of } \\
\text { interest. }\end{array}$ \\
\hline April 2, 2018 & $\begin{array}{l}\text { Indian Express and another whistleblower allegedly claimed that Deepak } \\
\text { Kochhar made enormous benefits from his closeness with Venugopal, } \\
\text { whose company Videocon was a large debtor to the Bank (Naraynan, 2018, } \\
\text { June 2). }\end{array}$ \\
\hline April 4, 2018 & $\begin{array}{l}\text { The Serious Fraud Investigation Office (SFIO) applies for approval by the } \\
\text { Ministry of Corporate Affairs to investigate ICICI Bank's INR } 32.50 \text { bn }\end{array}$ \\
\hline
\end{tabular}




\begin{tabular}{|c|c|}
\hline & loans to the Videocon group (Singh, 2019, October 25). \\
\hline May 23, 2018 & $\begin{array}{l}\text { The SEBI issued a notice to Chanda on dealings with Venugopal's group } \\
\text { and her husband Deepak Kochhar's NPRL. }\end{array}$ \\
\hline May 30, 2018 & $\begin{array}{l}\text { The ICICI Bank board decided to start an independent investigation in the } \\
\text { matter (Saha, 2018, May 30). }\end{array}$ \\
\hline June 6, 2018 & $\begin{array}{l}\text { The board appointed retired Supreme Court Judge Justice BN Srikrishna to } \\
\text { probe the matter. Chanda Kochhar went on an indefinite leave, which the } \\
\text { bank tried to hide by calling it her planned annual leave(Nair, 2018, June } \\
\text { 15) }\end{array}$ \\
\hline October 4, 2018 & $\begin{array}{l}\text { Chanda Kochhar resigned from her coveted post. The bank stated that the } \\
\text { ongoing enquiry would continue. Certain benefits would be extended after } \\
\text { the results of the enquiry were out. The board also accepted this as her early } \\
\text { retirement. Sandeep Bakshitook charge of MD \& CEO for five years } \\
\text { (Laskar, 2018, October 4). }\end{array}$ \\
\hline January 24,2019 & $\begin{array}{l}\text { The CBI lodged an FIR against Chanda, Deepak, and Venugopal over } \\
\text { approved loans' irregularities (Dsouza,2019, January 24). }\end{array}$ \\
\hline January 30, 2019 & $\begin{array}{l}\text { Justice BN Srikrishna panel inferred that Chanda had violated the bank's } \\
\text { by-laws and code of conduct. ICICI's board decided to recoup all bonuses } \\
\text { paid to Kochhar between April } 2009 \text { and March } 2018 \text {, and her resignation } \\
\text { was converted into her termination(Hetavkar, 2019, January 30). }\end{array}$ \\
\hline February 2, 2019 & ED files a complaint against Chanda Kochhar (Ohri, 2019, February 2) \\
\hline $\begin{array}{l}\text { November } 30, \\
2019\end{array}$ & $\begin{array}{l}\text { Chanda Kochhar decided to challenge her termination in court } \\
\text { (Unnikrishnan, 2019, December 10). }\end{array}$ \\
\hline January 10, 2020 & $\begin{array}{l}\text { The ED filed a charge sheet against Chanda and attached assets valued at } \\
\text { INR } 780 \mathrm{mn} \text { (Sharan, 2020, November 5). } \\
\text { The bank also filed a recovery suit against Chanda in Maharastra High } \\
\text { Court. The bank seeks to recover around INR } 120 \mathrm{mn} \text { that Chanda received } \\
\text { as part of the bonus and other benefits before being terminated (Vyas, 2020, } \\
\text { January 14). }\end{array}$ \\
\hline $\begin{array}{l}\text { September } \\
2020\end{array}$ & Deepak was arrested under the PMLA (Gupta, 2020, September 10). \\
\hline $\begin{array}{l}\text { November } \quad 4, \\
2020\end{array}$ & $\begin{array}{l}\text { The ED filed a charge sheet against Chanda \& Deepak Kochhar and } \\
\text { Venugopal Dhoot (Sarkar, 2020, November } 4 \text { ). }\end{array}$ \\
\hline December 1, 2020 & $\begin{array}{l}\text { Court refused to grant bail to Deepak (Sharma, 2020, December 1). The } \\
\text { Apex Court dismissed Chanda's appeal against her termination as the top } \\
\text { boss of the bank against the Maharastra High Court order. }\end{array}$ \\
\hline January 30,2021 & $\begin{array}{l}\text { The special court for PMLA summoned Kochhars, Venugopal, and others } \\
\text { who were accused of money laundering cases after taking cognisance from } \\
\text { the charge sheet filed by the ED (Shah, 2021, January 30). }\end{array}$ \\
\hline February 12,2021 & $\begin{array}{l}\text { Chanda Kochhar was granted bail on a bond of INR } 0.5 \mathrm{mn} \text {. She has been } \\
\text { directed not to leave the country without permission (Samervel, 2021, } \\
\text { February 13). }\end{array}$ \\
\hline March 12, 2021 & Venugopal granted bail (Bhalla, 2021, March 12). \\
\hline
\end{tabular}




\section{CONCLUSION}

A Mumbai's PMLA court called Chanda to appear before the court on February 12, 2021, connected with a money laundering case filed by the ED (Shah, 2021). In a detailed order, a special PMLA court held that it appeared that Chanda had misused her official position in sanctioning loans to Venugopal of Videocon group companies and got personal advantages. According to sources, the agency has established as the proceeds of crime at INR $720 \mathrm{mn}$, which was laundered through companies of Chanda Kochhar's husband, Deepak Kochhar (Shah, 2021). Following this summons by the special PMLA court, Chanda appeared before the court on February 12, 2020, and was granted bail on a bond of INR0.5 mn. The court instructed her to immediately deposit her passport to the court and would not be allowed to travel abroad without its permission (Samervel, 2021). On March 12, 2021, Dhoot has also been granted bail in the ICICI case (Bhalla, 2021).

A high-level probe into the scandal continues. The exact verdict on the case will unfold for justice to prevail and end up with such unethical practices and corporate governance failures!

\section{REFERENCES}

Bhalla, M. (2021, March 12). Videocon ex-promoter Venugopal Dhoot granted bail in ICICI BankChanda Kochhar case. Retrieved March 13, 2021, from https://economictimes.indiatimes.com/industry/banking/finance/banking/venugopal-dhootgranted-bail-in-icici-bank-chanda-kochhar-case/articleshow/81464465.cms

Choudhary, S. (2020, December 3). PMLA tribunal directs "status quo" on Chanda Kochhar's properties. Retrieved March 1, 2021, from https://www.businessstandard.com/article/companies/pmla-tribunal-directs-status-quo-on-chanda-kochhar-sproperties-120120301425_1.html

Choudhary, S. (2019, February, 2). Chanda Kochhar's fall from grace-here is how she was caught, step by step. Retrieved March 1, 2021, from https://www.businesstoday.in/top-story/chandakochhars-fall-from-grace-here-is-how-she-was-caught-step-by-step/story/321344.html

Choudhary, S. (2019, March 13). Videocon loan was ICICI credit panel decision: Chanda Kochhar to ED. Retrieved March 5, 2021, from https://www.businessstandard.com/article/companies/videocon-loan-was-icici-credit-panel-decision-chandakochhar-to-ed-119031301114_1.html

Dhamsana, I. (2019, January 25). Money trail: A timeline of CBI's probe into ICICI Bank-Videocon case. Retrieved March 6, 2021, from https://www.businessstandard.com/article/finance/money-trail-a-timeline-of-cbi-s-probe-into-icici-bank-videoconcase-119012501495_1.html

Dsouza, S. (2019, January 24). FIR Against Chanda Kochhar: What The CBI Alleges. Retrieved March 4, 2021, from https://www.bloombergquint.com/business/fir-against-chanda-kochharwhat-the-cbi-alleges

Gadgil, M. (2018, October, 5). Chanda Kochhar: The rise and fall of an icon. Retrieved March 1, 2021, from https://mumbaimirror.indiatimes.com/mumbai/other/the-rise-and-fall-of-anicon/articleshow/66079084.cms 
Gupta, Y. (2020, September 10). Explained: Why was Deepak Kochhar arrested by ED? All you need to know. Retrieved March 4, 2021, from https:/www.cnbctv18.com/finance/explainedwhy-was-deepak-kochhar-arrested-by-ed-all-you-need-to-know-6865181.htm

Hetavkar. N. (2019, January 30). Chanda Kochhar held guilty in the ICICI probe report, will lose her perks. Retrieved March 5, 2021, from https://www.businessstandard.com/article/finance/chanda-kochhar-violated-code-of-conduct-icici-probe-report119013001201_1.html

ICICI Bank History (n.d.). Retrieved March 14, 2021, from https://www.businessstandard.com/company/icici-bank-5418/information/company-history

ICICI-Videocon Case: Whistleblower Levels New Allegations In Letter To PM Modi 92018, 2021, June 2). NDTV. Retrieved March 3, 2021, from https://www.ndtv.com/business/icicivideocon-case-whistleblower-levels-new-allegations-in-letter-to-pm-modi-1861514

Jai, S. (2018, April 5). Supreme Energy's stake in NuPower sold at market rate: Deepak Kochhar. Retrieved March 6, 2021, from https://www.business-standard.com/article/companies/supremeenergy-s-stake-in-nupower-sold-at-market-rate-deepak-kochhar-118040500045_1.html

James, N. (2021, January 21). Money trap: At insolvency's doors, Dhoots forced to exit. Retrieved March 1, 2021, from https://www.thehindubusinessline.com/companies/at-insolvencys-doorsdhoots-forced-to-exit/article33485670.ece

Laskar, A. (2018, October 4). Chanda Kochhar quits as CEO of ICICI Bank, Sandeep Bakhshi to take over. Retrieved March 5, 2021, from https://www.livemint.com/Companies/0OVITPErq3KWdpPx980NWL/Chanda-Kochhar-quitsas-CEO-of-ICICI-Bank.html

Nair, V. (2018, June 15). Retired Judge BN Srikrishna To Lead Investigation Against Chanda Kochhar. Retrieved March 5, 2021, from https://www.bloombergquint.com/business/retiredjudge-bn-srikrishna-to-lead-investigation-against-chanda-kochhar

Naraynan, K. (2018, June 2). Complaint by ICICI insider forced board to probe Chanda Kochhar. Retrieved March 5, 2021, from https://indianexpress.com/article/business/businessothers/complaint-by-icici-bank-insider-forced-board-to-probe-chanda-kochhar-5200866/

Ohri, R. (2019, February 2). ED registers case against former ICICI Bank CEO Chanda Kochhar.Retrieved March 4, 2021 from https://economictimes.indiatimes.com/news/politicsand-nation/ed-registers-case-against-former-icici-bank-ceo-chandakochhar/articleshow/67799364.cms

Saha, M. (2018, May 30). ICICI Bank to form independent panel to probe allegations against Chanda Kochhar. Retrieved March 2021, from https://www.thehindu.com/business/Industry/icici-bank-to-hold-independent-probe-intoallegations-against-chanda-kochhar/article24034206.ece 
Samervel, R. (2021, February 13). Chanda Kochhar granted bail, can't leave India sans court nod. Retrieved March 6, 2021, from https://timesofindia.indiatimes.com/city/mumbai/chandakochhar-granted-bail-cant-leave-india-sans-court-nod/articuleshow/80889248.cms

Sarkar, K. (2020, November 4). ED files charge sheet against ex-ICICI Bank chief Chanda Kochhar, her husband. Retrieved March 3, 2021, from https://www.hindustantimes.com/businessnews/ed-files-chargesheet-against-former-icici-bank-chief-chanda-kochhar-and-her-husbandvideocon-group-md-venugopal-dhoot-also-named-in-fraud-case/storyQ06Afu3jQnqPradCGevr0L.html

Shah, C. (2021, January 30). ICICI Bank case: Special court accepts ED's complaint, summons Kochhars.Retrieved March 3, 2021, from https://www.hindustantimes.com/cities/mumbainews/icici-bank-case-special-court-accepts-ed-s-complaint-summons-kochhars101612017745532.html

Sharan, A. (2020, November, 5). ED files first charge sheet in ICICI loan case. Retrieved March 3, 2021, fromhttps://mumbaimirror.indiatimes.com/mumbai/crime/ed-files-first-chargesheet-inicici-loan-case/articleshow/79052249.cms

Sharma, P.(2020, December 1). Court refuses bail to Deepak Kochhar in money laundering case. Retrieved March 3, 2021, from https://www.indiatoday.in/business/story/court-refuses-bail-todeepak-kochhar-in-money-laundering-case-1745831-2020-12-01

Singh, S. (2018, March, 29). Videocon gets Rs 3250-crore loan from ICICI Bank, bank CEO's husband gets sweet deal from Venugopal Dhoot. Retrieved March 6, 2021, from https://indianexpress.com/article/express-exclusive/videocon-gets-rs-3250-cr-loan-from-icicibank-chanda-kochhars-husband-gets-sweet-deal-from-venugopal-dhoot-5115267/

Singh, D. (2019, October 25). SFIO starts probe in deals between Videocon and Deepak Kochhar. Retrieved March 5, 2021, from https://www.indiatoday.in/india/story/sfio-starts-probe-indeals-between-videocon-and-deepak-kochhar-1612822-2019-10-25

Singh, D. (2020, December 8). Deepak Kochhar threatened to ruin my name by declaring ICICI bank loans as NPAs, says Venugopal Dhoot. Retrieved March 1, 2021, from https://www.indiatoday.in/india/story/deepak-kochhar-threatened-to-ruin-my-name-bydeclaring-icici-bank-loans-as-npas-venugopal-dhoot-1747624-2020-12-08

Unnikrishnan, D. (2018, April 3). Videocon loan case: ICICI Bank sanctioned Rs 650 cr loan against Dhoot's group company that had a turnover of just Rs $75 \mathrm{cr}$. Retrieved March 5, 2021, from https://www.firstpost.com/business/videocon-loan-case-icici-bank-gave-rs-650-cr-loan-todhoots-group-company-that-had-a-turnover-of-just-rs-75-cr-4416037.html

Unnikrishnan, D. (2018, June 1). Whistleblower in ICICI-Videocon case levels new allegations against Kochhar in letter to prime minister. Retrieved March 5, 2021, from https://www.firstpost.com/business/whistleblower-in-icici-videocon-case-levels-newallegations-of-wrongdoing-against-kochhar-sends-letter-detailing-charges-to-pm-financeminister-4491163.html 
Unnikrishnan, D. (2019, December 10). Videocon loan case: With Chanda Kochhar knocking HC's door challenging termination, ICICI board's actions are back in spotlight. Retrieved March 3, 2021, from https://www.firstpost.com/business/videocon-loan-case-with-chanda-kochharknocking-hcs-door-challenging-termination-icici-boards-actions-are-back-in-spotlight7763041.html

Vyas, M, (2020, January 14). ICICI Bank slaps Rs 12 cr recovery suit on Chanda Kochhar. Retrieved March 3 , 2021, from https://economictimes.indiatimes.com/industry/banking/finance/banking/icici-bank-slaps-rs12-cr-recovery-suit-on-chanda-kochhar/articleshow/73237797.cms?from=mdr

\section{Copyrights}

Copyright for this article is retained by the author(s), with first publication rights granted to the journal. This is an open-access article distributed under the terms and conditions of the Creative Commons Attribution license (http://creativecommons.org/licenses/by/4.0/) 